\title{
Exploring career change transitions through a dialogic conceptualization of science teacher identity
}

\author{
Lara Smetana \\ Loyola University Chicago \\ Ali Kushki \\ Loyola University Chicago, akushki@luc.edu
}

Follow this and additional works at: https://ecommons.luc.edu/education_facpubs

Part of the Science and Mathematics Education Commons, and the Secondary Education and Teaching Commons

Author Manuscript

This is a pre-publication author manuscript of the final, published article.

\section{Recommended Citation}

Smetana, L. K. T., \& Kushki, A. (2020). Exploring career change transitions through a dialogic conceptualization of science teacher identity. Journal of Science Teacher Education, 32(2), 167-187. https://doi.org/10.1080/1046560X.2020.1802683

This Article is brought to you for free and open access by the Faculty Publications and Other Works by Department at Loyola eCommons. It has been accepted for inclusion in Education: School of Education Faculty Publications and Other Works by an authorized administrator of Loyola eCommons. For more information, please contact ecommons@luc.edu. c) $($ ())

This work is licensed under a Creative Commons Attribution-Noncommercial-No Derivative Works 3.0 License. (c) Taylor \& Francis, 2020. 
Running Head: DIALOGIC VIEW OF CAREER CHANGER SCIENCE TEACHER IDENTITY

\title{
Exploring Career Change Transitions Through a Dialogic Conceptualization \\ of Science Teacher Identity
}

\begin{abstract}
Research into the construct of science teacher identity has gained momentum over the past decade in an effort to achieve a more comprehensive, holistic understanding of teacher learning and development. As yet few studies have examined the unique identity challenges of science teacher career changers. Akkerman and Meijer's (2011) dialogical approach to the conceptualization of teacher identity informed this longitudinal, qualitative study exploring the different identity aspects, or I-positions, of two individuals who had changed careers to teach high-school biology. The study identified moments of disequilibrium experienced by the participants and explored how they each eventually restored equilibrium. Analysis included tabulation of data using preliminary categories of multiplicity and unity, discontinuity and continuity, social and individual, and the participants' internal negotiations. Findings revealed various I-positions and the disequilibrium that resulted as competing I-positions emerged during participants' transition to a new career in teaching. However, there was also a common theme of participants eventually integrating these competing I-positions in an effort to find unity and continuity. The need for teacher preparation programs to support career changers in negotiating I-position conflicts such that they do not become insurmountable is discussed. Implications of depicting identity from a developmental perspective are offered for teacher preparation programs as well as teacher education research.
\end{abstract}

\section{Introduction}

The construct of science teacher identity - who teachers are, who they are becoming, and who they want to be (Varelas, 2012) - has been a growing focus of study over the past decade. It 
is increasingly understood that to achieve a more comprehensive, holistic understanding of teacher learning and development, the affective and relational aspects of teaching require attention alongside cognitive and other factors (Avraamidou, 2014). These lines of research into science teacher identity development recognize that research must expand beyond investigations into science teacher candidates' acquisition and performance of particular understandings, knowledge, and skills about science, pedagogy, and learners. According to Day (2012),

it is necessary to consider the importance of the part the person plays within the professional. This is essential because a raft of literature points to teaching as an essentially human endeavour in which who the teacher is as important as what she teaches. (p. 15) Despite the growing interest in science teacher identity overall, there is a need for further exploration into a broader range of teacher populations across diverse geographical and sociocultural contexts (Avraamidou, 2019). This study is focused on science teacher career changers, an under-investigated group (Troesch \& Bauer, 2017; Wilson \& Deaney, 2010). This group is of interest not just because of their growing numbers, but also their potential to help fill science teaching shortages (Grier \& Johnston, 2012; Watters \& Diezmann, 2015). Currently, "there exist a gap in the literature on TE (teacher education) policy regarding how career changers are supported in achieving their potentials, given their particular needs and characteristics" (Varadharajan \& Schuck, 2017, p. 85). How do they transition from one professional field, role, and community to another? What can teacher preparation programs do to support this transition?

We framed this study within Akkerman and Meijer's (2011) dialogical approach to the conceptualization of teacher identity. A dialogic perspective on career-changer science teacher identity links micro personal and macro societal factors across career changer teachers' intrinsically different professional periods to reveal the sources of the individual decisions, 
tensions, negotiations, etc. This, in turn, gives insights into and about their unique experiences and needs.

The following questions guided this qualitative two-case study (Creswell \& Creswell, 2018) of two career changers:

1. What aspects of identity were revealed as the two participant teachers decided to change careers?

2. What moments of disequilibrium did these teachers experience during the transition from one career to another?

3. How did these teachers restore equilibrium?

\section{Science Teacher Career Teachers}

Research into career-changers to science teaching has slowly gained momentum. Eifler and Pottholf (1998) define a career-changer teacher as "someone who is over 25, and possesses life experiences resulting either from previous careers and/or from parenthood, potentially enabling them to bring important assets, such as maturity and expertise to teaching” (p. 85). Individuals may decide to change careers and pursue teaching due to a variety of factors including seeking more flexibility for family life, a desire to make a difference, or dissatisfaction in a previous job or workplace (Anthony \& Ord, 2008; Grier \& Johnston, 2009; Wilson \& Deaney, 2010). Watters and Diezmann (2015) highlight "the experiences that ex-scientists and engineers bring from their professional life including applied knowledge or their subject matter, people-oriented skills, eagerness to share with colleagues, good communication skills and tolerance of diversity" (p. 164). These attributes have made career changers a focus of policy efforts aimed at recruiting teachers to fill gaps, particularly in the sciences (Varadharajan \& Schuck, 2017). 
However, the varied personal and professional experiences career changers bring also present unique identity challenges as they transition from one work community to another. The transition from being a professional to a student again is one challenge (Grier \& Johnston, 2009), as is determining how to draw from one's previous science-related experiences (Grier \& Johnston, 2012). A study of preservice career-change teachers at the conclusion of a practice teaching semester noted that they shared many of the anxieties of non-career-change beginning teachers related to personal lives, classroom management, and preparation albeit "second career student teachers find many of their concerns are magnified"' (Haggard, Slostad, \& Winterton, 2006, p. 327). In Watters and Diezmann's (2015) exploration of 14 career changers' experiences during their first three years of entering teaching, it was found that the unique challenges facing career-change professionals were often overlooked by administrators and colleagues.

Despite the interest in recruiting career changers, and acknowledgment that their transition to teaching is unique, there is limited empirical research investigating how best to support this group. "Research on career changers is in its infancy with more questions than answers at this stage" (Watters \& Diezmann, 2015, p. 190). Wilson and Deaney (2010) argue that identity formation issues are of particular pertinence for career changers who are in the midst of developing a "new work role identity" (p. 170). The doubts, dilemmas, and uncertainties this unique group of science teachers faces, their ability to address and resolve these, and how their decision to stay in the profession would be affected are among the questions that the present study addresses.

\section{Science Teacher Identity}

Science teacher identity has been conceptualized and studied in a variety of ways, presenting researchers with challenges and opportunities. Within the scholarship, identity has 
DIALOGIC VIEW OF CAREER CHANGER SCIENCE TEACHER IDENTITY

become somewhat of an umbrella term that has come to encompass a wide range of interpretations and approaches. It has been used to explore a variety of issues, including teachers' understandings about science (Helms, 1998), teachers' reform-minded pedagogical practices (Luehmann, 2007; Saka, Southerland, Kittleson, \& Hutner, 2013; Smith, 2005), teachers’ negotiation of contexts (Marco-Bujosa, McNeill \& Friedman, 2019; Upadhyay, 2009), teacher preparation (Danielowich, 2012), and how social makers such as race, class, and gender intersect with identity development (Moore, 2012; Rivera Maulucci, 2013).

Despite the diverse conceptualization, there is consensus among researchers that identity is best described as a process, which can be explored in terms of how science teachers construct and continually reconstruct their identities, rather than a product (Avraamidou, 2014; CalabreseBarton, Kang, Tan, O’Neill, Bautista-Guerra, \& Brecklin, 2013; Olsen, 2008). A focus on process over product rejects static conceptualizations of the self and instead emphasizes the emergent nature of identity, its situatedness within contextual boundaries, and teacher agency (Beijaard, Meijer, \& Verloop, 2004).

An understanding of identity as a process raises questions about the pathways these developmental processes take and the factors and conditions that influence them. Several studies have examined the role of teachers' life experiences up to and including their teacher preparation, concluding that there is great potential for teacher preparation program experiences to tap into and engage with prior life experiences that together shape teacher identity (Avraamidou, 2019; Bukor, 2015; Eick \& Reed, 2002; Grier \& Johnston, 2012).

Other process-oriented studies have looked specifically at the role of tensions and conflicts in the formation of teacher identity. Several studies report that a degree of dissonance was found to be beneficial and lead to growth (Danielowich, 2012; Varelas, House, \& Wenzel, 
2005). However, a case study described by Saka et al. (2013) cautions of how these tensions can be counterproductive and debilitating for novice teachers, particularly if they are not well supported in anticipating and working through the challenges. Hong, Greene, and Lowery (2017) further highlight the need for supporting career change teachers in particular as they negotiate the tensions that arise between the multiple aspects of their identities in order to prevent burnout. This may come in the form of a space, created by teacher educators, for exploring and unpacking the disequilibrium as a part of the identity formation process. Such a space is evident in the experiences of the novice teachers studied by Marco-Bujosa, McNeil, and Freidman (2019) who benefited from opportunities for regular reflection and social support throughout their first year, particularly as they sought to challenge structural inequities within their schools. The current study furthers efforts exploring the complexity of novice science teachers' professional identity development, specifically focusing on individuals who enter teaching after making a career change.

\section{Dialogic approach to teacher identity}

In the present study, we draw upon Akkerman and Meijer's (2011) dialogical approach to the conceptualization of teacher identity. This approach comes from the perspective of both-and and allows for exploring the dynamic negotiation of varied and seemingly conflicting dimensions of identity: both unitary and multiple, both continuous and discontinuous, and both individual and social. The conceptualization helps address the persistent ambiguity in the extant literature around the individual and social aspects of the self and how they relate. That is, to capture the full complexity of teacher identity, Akkerman and Meijer (2011) combine modern and postmodern interpretations, considering the two in relation to, not in negation of, one another. Contrary to the long-standing modern reading of identity as a singular, continuous, and 
individual entity, the post-modern conceives of identity as multiple, discontinuous, and social (Akkerman \& Meijer, 2011). The researchers break away from the modern-postmodern duality found in the identity literature and put forth a three-component framework in which these polarized components are dialogically related to one another. See Table 1.

Table 1. Dimensions of a Dialogic Approach to Teacher Identity (Akkerman \& Meijer, 2011)

\begin{tabular}{|l|l|}
\hline Multiplicity \& Unity & $\begin{array}{l}\text { Teacher identity consists of multiple I-positions which coexist in } \\
\text { dialogical relations, with any gaining temporary dominance. } \\
\text { Unity is established through a negotiated, dialogical space that } \\
\text { creates harmony and coherence via self-dialogue. }\end{array}$ \\
\hline $\begin{array}{l}\text { Discontinuity \& } \\
\text { Continuity }\end{array}$ & $\begin{array}{l}\text { Teacher identity is fluid and dynamic as a function of which I } \\
\text { positions are called into service in what context, and so, } \\
\text { discontinuous. That said, continuity is maintained by alignment } \\
\text { of past, present, and future experiences in narrations as well as } \\
\text { by patterned, culturally-mediated I-position shifts. }\end{array}$ \\
\hline Social \& Individual & $\begin{array}{l}\text { Teacher identity involves interconnections between the } \\
\text { individual and social planes. A teacher is a social participant as } \\
\text { well as an autonomous, agentic individual. }\end{array}$ \\
\hline
\end{tabular}

The dialogic approach is particularly relevant as a framework for investigating identity issues related to science teacher career changers because of the potential competing voices (referred to as I-positions) that emerge with the transition from one career to another. Multiple Ipositions can exist within any given individual, making them prone to conflict and rivalry for dominance. Left unresolved, conflicting I-positions can produce indecisiveness, inconsistency in thought and action, etc. Within the context of teacher education, Beijaard et al. (2004) concluded, "Professional identity formation is often presented as a struggle, because (student) teachers have to make sense of varying and sometimes competing perspectives, expectations, and roles that they 
DIALOGIC VIEW OF CAREER CHANGER SCIENCE TEACHER IDENTITY

have to confront and adapt to" (p. 115). Understanding the negotiation of competing dimensions

- "the tension of being both many and one at the same time" (Akkerman \& Meijer, 2011, p. 317)

- is part of better understanding how to support novice teachers (Antink-Meyer \& Brown, 2017)

and especially those that have recently changed careers (Hong et al., 2017).

\section{Methods}

\section{Study Approach}

This qualitative, two-case study (Creswell, 2013) investigates, from a dialogic viewpoint, how novice career-changer teachers negotiate multiple I-positions in relation to their teacher self, including the doubts, dilemmas, and uncertainties that this unique group of teachers experiences. The in-depth, exploratory nature of a case study approach allows for examination of the complexity of science teacher career changer identity. Each participant serves as a single case, or bounded system, of which to make meaning through the examination of multiple sources of information. The inclusion of the two cases allows for comparison and more compelling interpretations (Merriam \& Tisdell, 2015).

\section{Context}

The study is situated within a 13-month graduate level secondary science teacher preparation program at a small midwestern university in a large urban center. The full-time program is field based. That is, the majority of instructional time takes place in schools and community settings where teacher candidates and faculty work in partnership with teachers and other educational professionals who are positioned as co-teacher educators. Teacher candidates have extended time in multiple classroom settings prior to a six-month student teaching placement. The program is focused on preparing teachers to work in culturally and linguistically diverse and economically disadvantaged school settings within the urban center. 


\section{Participants}

The two participants (See Table 2) were selected because they represented unique cases:

Both were career changers, somewhat unique within our teacher preparation program despite

being emphasized in recruitment for other programs. Both were white women pursuing a

Master's in Secondary Education with certification for teaching high school biology. Gloria was

completing a six-month student teaching placement, Thelma was in her first year of teaching.

Pseudonyms are used throughout. Participants were recruited by the second author who was not involved in the teacher preparation program.

Table 2. Participants

\begin{tabular}{|c|c|c|}
\hline Participant & Teaching Context & Career Change Decision \\
\hline Gloria & $\begin{array}{l}\text { Gloria is completing student teaching } \\
\text { in a public high school in the city } \\
\text { where she completed her teacher } \\
\text { preparation program. She is excited to } \\
\text { have accepted a full-time job teaching } \\
\text { in the same district for the upcoming } \\
\text { year. She teaches a mix of biology } \\
\text { course levels for freshman through } \\
\text { senior year students. } \\
\text { School Data: } \\
\text { Student Mobility } 11 \% \\
\text { Low Income } 80 \% \\
\text { Limited English } 18 \% \\
\text { Students with IEPs } 13 \% \\
\text { White } 11 \% \\
\text { Black } 25 \% \\
\text { Hispanic } 42 \% \\
\text { Asian } 18 \% \\
\text { Am. Indian } 1 \% \\
\text { Two or More } 2 \% \\
\text { Pacific Islander } 1 \%\end{array}$ & $\begin{array}{l}\text { Gloria was reluctant to leave her } \\
\text { career in environmental and } \\
\text { agricultural education, which } \\
\text { she loved, but teaching high } \\
\text { school was an obvious next } \\
\text { move. She was also motivated to } \\
\text { make a difference in students' } \\
\text { school experience given the } \\
\text { inequities she noticed across the } \\
\text { communities she worked in. } \\
\text { Prior to making the career } \\
\text { change she had worked with } \\
\text { varied students of all ages } \\
\text { (preschool through college) and } \\
\text { backgrounds for over } 10 \text { years } \\
\text { across three different states. }\end{array}$ \\
\hline Thelma & $\begin{array}{l}\text { Thelma had completed her student } \\
\text { teaching in the same school district as } \\
\text { Gloria a year prior and is completing } \\
\text { her first year as a full-time classroom } \\
\text { teacher in another district. This satellite }\end{array}$ & $\begin{array}{l}\text { Thelma was unsatisfied with her } \\
\text { career as a veterinary doctor, but } \\
\text { the decision to enter teaching } \\
\text { was one that she reached after } \\
\text { much deliberation, considering }\end{array}$ \\
\hline
\end{tabular}




\begin{tabular}{|c|c|c|}
\hline & $\begin{array}{l}\text { city public high school offers several } \\
\text { unique academic programs, such as } \\
\text { Forensics and Biomedical Science, that } \\
\text { attracted her. She currently teaches a } \\
\text { mix of Biology and Forensic Science } \\
\text { courses for freshman through senior } \\
\text { year students. } \\
\text { School Data: } \\
\text { Student Mobility } 9 \% \\
\text { Low Income } 48 \% \\
\text { Limited English } 4 \% \\
\text { Students with IEPs } 11 \% \\
\text { White 35\% } \\
\text { Black } 22 \% \\
\text { Hispanic } 38 \% \\
\text { Asian } 2 \% \\
\text { Am. Indian } 0 \% \\
\text { Two or More } 3 \% \\
\text { Pacific Islander } 0 \%\end{array}$ & $\begin{array}{l}\text { a variety of possible options. } \\
\text { Prior to making the career } \\
\text { change, she had earned a degree } \\
\text { in veterinary medicine and } \\
\text { practiced full-time for three } \\
\text { years. }\end{array}$ \\
\hline
\end{tabular}

\section{Data Collection}

Data were collected from the following sources: teacher preparation coursework and student teaching artifacts collected throughout the 13-month program, researcher field notes from two to three classroom visits, one written reflection activity, two semi-structured interviews, and one written member checking activity. Together, these data sources revealed insight into participants' thoughts, beliefs, views, and emotions as well as their teaching practice.

\section{Coursework, teaching artifacts and field notes}

Lesson and unit plans, written rationale statements, and teaching reflections provided a sense of how participants designed instruction and enacted their ideas and understandings in different settings and at different points in time. Artifacts collected across the teacher preparation program and into student teaching and, in the case of Thelma, the first year of teaching revealed 
insights into how instructional practices evolved. Researcher field notes taken during three classroom observations (Thelma) and two classroom observations (Gloria) captured researcher reflections, interpretations, and questions, and offered additional contextual information about the teaching contexts and participants. An initial review of these practice-based data informed the development of the written reflection activity, while a more in-depth analysis took place following the interviews.

Written reflection activity

We requested participants engage in a written reflection activity prior to scheduling interviews. After confirming consent, the second author emailed prompts to participants, who completed the activity at their own pace. The three main prompts required participants to provide a brief description of their academic and professional careers, explain important transitional moments in their academic and professional careers and why these stood out to them, and discuss if and what influences these transitional moments had on their current instructional practices. We speculated the written reflection activity would allow thinking time about past experiences, and

thus, provide more accurate, representative information about the participants' lived experiences and current thoughts and practices. Reviewing the written reflections allowed us to hone the subsequent interview protocol.

Interviews

Having collected and studied written reflections, we developed interview protocols and conducted semi-structured interviews with each participant. The goal of these interviews was to further explore and clarify ideas that surfaced in the initial review of practice-based data and in the written reflection activity. Some questions such as "Can you tell me a bit more about the classes you were teaching this year and the school that you're working in?" were included in the 
interview protocols for both participants. However, to develop individualized interview protocols, both researchers read written reflections, highlighted ambiguous sections and noted areas for further probing, and articulated follow-up questions. These questions were then prioritized in order to keep the interviews, conducted by the second author who had no prior involvement with participants, to about 30 minutes each. During the interviews, relevant chunks of the written activity responses were read to participants, who were requested to elaborate on the responses. For instance, one participant was asked 'I'd like to ask you a bit more about your decision to change careers. In your reflection you wrote [quote from written reflection]. Can you say more about that comment? What was it that you were unhappy about?" Interviews were audio recorded, and subsequently transcribed by an external company (rev.com) for analysis. Written member check activity

Towards the end of the study, we provided written summaries of initial findings to participants to check that we had not misrepresented them, to reduce researcher bias, and to increase trustworthiness of findings (Creswell, 1994). The three prompts provided for this activity included: Is there anything that you feel we have misrepresented in this summary? Is there anything else you would like to add? Is there anything you would like to say about this school year, which is just beginning? Participants could opt to respond in writing or schedule a phone call. Both participants decided to respond in writing.

\section{Data Analysis}

Analysis focused on uncovering the nature of these two career-changers' developing science teacher identities through a dialogic conceptualization of teacher identity. Akkerman and Meijer's (2011) framework provided guidance for deductive coding. Preliminary categories of multiplicity and unity, discontinuity and continuity, social and individual, and negotiations 
served to organize the data into tables (See Table 3). Within the category of multiplicity and unity, we especially attended to what I-positions emerged, any reflections on as well as tensions and negotiations between different I-positions. Within the category of discontinuity and continuity, we were interested in examples of temporary or situational I-positions as well as common threads that pulled the various I-positions together. Within the category of social and individual, we were interested in examples of the influence of others and/or the environment. Within the category of negotiation, we were interested in dynamic negotiation between disequilibrium and restored equilibrium. As we annotated descriptive and interpretive comments on copies of the data, additional codes inductively emerged. These codes were specific to the particular I-positions identified for each participant and included novice/expert, informal educator, relationship-builder, social justice proponent. Here, the analysis of practice-based data provided useful insight into participants' enacted identities and allowed for triangulation with other data sources. Guided by the research questions and grounded in the observed patterns and data, assertions about each case were crafted and narratives were developed to describe the salient features of each participants' unique story (Creswell, 2013).

The involvement of one researcher (first author) who was as an instructor for two courses in the fall semester of the teacher preparation program and another researcher (second author) with no involvement in the program allowed for different, insider and outsider, perspectives. While there was strong agreement amongst our application of broad categories and more specific codes (95\%), discussion was important to resolve any inconsistencies and push thinking forward. 
DIALOGIC VIEW OF CAREER CHANGER SCIENCE TEACHER IDENTITY

Table 3. Analysis Summary Table

\begin{tabular}{|c|c|c|c|}
\hline Category & Code & Description & Example \\
\hline $\begin{array}{l}\text { Multiplicity \& } \\
\text { Unity }\end{array}$ & I-position & $\begin{array}{l}\text { Sub-identity; a voiced } \\
\text { position, personality or } \\
\text { viewpoint }\end{array}$ & $\begin{array}{l}\text { Out of all my subjects, science is the one that } \\
\text { was my favorite. I liked everything about it... I } \\
\text { was in love with the subject. I wanted this to be } \\
\text { part of what I did. [Thelma] }\end{array}$ \\
\hline \multirow[t]{2}{*}{$\begin{array}{l}\text { Discontinuity } \\
\text { \& Continuity }\end{array}$} & $\begin{array}{l}\text { Situational I- } \\
\text { position }\end{array}$ & $\begin{array}{l}\text { a specific identity at a } \\
\text { particular moment in a } \\
\text { specific context; indicates } \\
\text { a particular situation is } \\
\text { evoking particular } \\
\text { elements of the self }\end{array}$ & $\begin{array}{l}\text { I think I'm working now in a slightly different } \\
\text { capacity where I'm not as much a mentor and } \\
\text { buddy, and I have to be shifting into this new } \\
\text { role where sometimes I have to be mean to the } \\
\text { students. And I never had to be mean before. } \\
\text { [Gloria] }\end{array}$ \\
\hline & $\begin{array}{l}\text { Consistent } \\
\text { sense of self }\end{array}$ & $\begin{array}{l}\text { Signifies a common } \\
\text { thread that pulls I- } \\
\text { positions together; } \\
\text { alignment of past, } \\
\text { present, and future } \\
\text { experiences }\end{array}$ & $\begin{array}{l}\text { But the part that really appealed to me most of } \\
\text { all was working with the high school students. } \\
\text { They were really the highlight of my day, and } \\
\text { because I only worked with them seven months } \\
\text { out of the school year, I spent five months of } \\
\text { the year in the winter kind of bummed out, and } \\
\text { I missed working with young people. And so I } \\
\text { figured that was probably a good sign that I } \\
\text { should move towards a position and a career } \\
\text { where I worked with young people for the } \\
\text { majority of the time and that was the basis of } \\
\text { my work. [Gloria] } \\
\text { I think that's the goal, is to kind of bring in } \\
\text { more of my medical stuff into my classroom. } \\
\text { [Thelma] }\end{array}$ \\
\hline \multirow[t]{2}{*}{$\begin{array}{l}\text { Social \& } \\
\text { Individual }\end{array}$} & $\begin{array}{l}\text { Internal } \\
\text { position }\end{array}$ & Unique, individual agent & $\begin{array}{l}\text { I was frustrated because it was so easy for me } \\
\text { (previously) to use agriculture as sort of a } \\
\text { vehicle to teach all of these different things } \\
\text { about the world and about social and } \\
\text { emotional learning. But those very same things } \\
\text { I learned can be taught through biology. } \\
\text { [Gloria] }\end{array}$ \\
\hline & $\begin{array}{l}\text { External } \\
\text { position }\end{array}$ & $\begin{array}{l}\text { Influence of social } \\
\text { interactions; } \\
\text { internalization of the } \\
\text { social world - signifies } \\
\text { an aspect of the social } \\
\text { world } \\
\text { that has become part of } \\
\text { one's identity }\end{array}$ & $\begin{array}{l}\text { There were some... that were just totally trying } \\
\text { to talk me out of it. Totally being like, 'You're } \\
\text { going to take a pay cut, you know.' And like, } \\
\text { 'Are you sure you want to do this? You're a } \\
\text { veterinarian, why would you want to do this?' } \\
\text { [Thelma] } \\
\text { But me and my classmates, we have a group } \\
\text { meet, so just sometimes we talk to each other } \\
\text { and just message each other about some crazy } \\
\text { things that happened during a classroom, and } \\
\text { then we'd talk about how we handled it and } \\
\text { what, that kind of thing was really helpful. } \\
\text { So yeah, I would say really just like talking to } \\
\text { other people and knowing how they've handled } \\
\text { situations, similar situations. That reminder } \\
\text { that it's okay, you don't have to have it all } \\
\text { figured out right now. [Gloria] }\end{array}$ \\
\hline
\end{tabular}


DIALOGIC VIEW OF CAREER CHANGER SCIENCE TEACHER IDENTITY

\begin{tabular}{|c|c|c|c|}
\hline Negotiations & Disequilibrium & $\begin{array}{l}\text { Tensions, doubts, } \\
\text { dilemmas, and/or } \\
\text { uncertainties }\end{array}$ & $\begin{array}{l}\text { I didn't want to move up in my position } \\
\text { because once I moved up, I would either stop } \\
\text { farming, which I loved, and I would stop } \\
\text { working with young people, which I loved. } \\
\text { [Gloria] }\end{array}$ \\
\hline & Self-dialogue & $\begin{array}{l}\text { Consideration of varying } \\
\text { intentions and priorities } \\
\text { within a negotiated, } \\
\text { dialogical space }\end{array}$ & $\begin{array}{l}\text { I was successful in veterinary school, and as a } \\
\text { veterinarian. But I was unhappy in practice. } \\
\text { [Thelma] }\end{array}$ \\
\hline & Equilibrium & $\begin{array}{l}\text { Resolution of tensions, } \\
\text { doubts, dilemmas, and/or } \\
\text { uncertainties }\end{array}$ & $\begin{array}{l}\text { It's more like reconciling what I learned in } \\
\text { school with the in and out challenges of daily } \\
\text { life in the classroom...I have a lot of goals that } \\
\text { I am still just setting out on... The great thing } \\
\text { about teaching is I get a new chance everyday } \\
\text { to do a little better. [Thelma] }\end{array}$ \\
\hline
\end{tabular}

\section{Findings}

Finding are reported in relation to each of the three research questions. First, we present the various I-positions each participant revealed as we explored their desire to change careers (research question 1). Personal experiences with science, teaching and learning relevant to these I-positions are uncovered. Next, we present instances of disequilibrium during the participants' transitions to teaching (research question 2) as well as how each participant teacher overcame Iposition conflicts and eventually restored equilibrium (research question 3).

\section{I-positions: Personal experiences with science, teaching and learning}

As we investigated the experiences of two career changers, Thelma and Gloria, both revealed various I-positions, or aspects of their identity. Analysis also uncovered personal experiences with science, teaching, and learning found to have been influential in their decisions to change careers. We summarize these below.

Thelma - scientist, lover of learning, successful student, seeking fulfillment 
DIALOGIC VIEW OF CAREER CHANGER SCIENCE TEACHER IDENTITY

Thelma revealed strong I-positions as a scientist, a lover of learning, one who had experienced success in academic pursuits, a professional, and one who seeks fulfillment in her career.

Thelma always felt drawn to science and her science classes in school. Beginning in "seventh grade", Thelma recalls in an interview, "I was really like, this is the subject that... out of all my subjects, science is the one that was my favorite. I liked everything about it". As a high school student, Thelma became fascinated with anatomy and physiology specifically, as she reveals in a written reflection, "I can remember specific videos they showed in class that completely fascinated me; an open-heart surgery, an animation of a white blood cell hunting down and devouring a bacterial invader. They set me on my science education and career path." As a classroom teacher, Thelma enjoys the renewed relationship with the science content, which contributed to her continuity of self. "I have had some moments teaching this year where I get goosebumps, I love the material so much and I knew that I was in the right field," she shares in the written reflection. In teaching, she feels reconnected with the science content that she always enjoyed and with the process of learning.

Thelma's strong I-position of a lover of learning not only helped her to successfully pursue and complete a veterinary medical degree, but also led to her wanting a change. Her veterinary practice became mundane and so while she was accomplished, she did not feel completely fulfilled intellectually in her work. She considered a variety of alternate career options, including medical research, but ultimately decided to pursue teaching. She explains in the written activity,

I was successful in veterinary school and as a clinician, but I was unhappy in practice. When I thought about what made me happy it was school...I think what education did for 
me. It gave me the passion and the skills to be successful life long and I think how amazing would that be to pass on.

Given Thelma's powerful and positive experience in middle and high school science, it is perhaps not surprising that the I-position of a lover of learning and science would influence her career change decision.

The decision was further supported by a visit to the high school where a former college classmate was teaching. This classmate, Thelma recalled in the interview, had been a serious student of both science and education. In Thelma's eyes, she was also a professional.

I remember her going to all these classes with me. And I knew that she was also taking education classes...Almost everyone in that program was pre-med or pre-dent or pre-vet. And she was going to be a teacher, and that totally stuck out with me. Visiting the classmate's school and shadowing her for a day, Thelma found "it just felt like it was the right place for me", as reveals in the interview. She left thinking to herself, she adds in the interview, "Yeah, this is totally what I want to be around and involved in."

Not everyone was supportive of her decision, however. Some questioned why she would want to take a pay cut. Others would remind her of "all that time that you spent" in veterinary school. Despite the social pressure to stay in her veterinary profession, Thelma's internal desire for a change and fulfillment in career won over. While others might have seen the change as giving up, she did not. "It wasn't like I couldn't be a vet. It wasn't like I went through all this and now I can't do it. It was just that I wasn't fulfilled doing it, so I never got a reward from it," she reflected in the interview. Enjoying personal fulfillment from her career was a part of Thelma's identity, and perhaps complemented her love of learning. As will be explored further in the next 
section, Thelma did not shy away from challenges when she saw them as part of something personally meaningful.

While external validation proved less important than her own internal desires, analysis indicated that Thelma enjoyed the sense of confidence that comes with having, and being recognized as having, a degree of expertise. This I-position of being a professional also emerges in Thelma's decision to pursue a master's degree in secondary education, prior to entering the teaching profession. Thelma understood that teaching high school science entailed more than understanding the science content, and that there was a new body of knowledge and expertise to gain. She recalled in the interview,

I really wanted to get a degree in teaching. Probably, with my veterinary degree, I probably could teach without going to get a Master's...But I didn't want to do that. I wanted to be an educator. I had the dream to be an educator so I needed to know how to do it, so that I could do it well.

Data analysis suggests that Thelma felt entering a formal teacher education program that would lead to a Master's degree in Secondary Education en route to her new career as a high school teacher would afford her this degree of confidence, similar to what she saw in the former classmate she spent time shadowing.

Gloria - scientist, informal science educator, relationship builder, and social justice proponent Gloria revealed strong I-positions, including scientist, informal science educator, relationship builder, and social justice proponent. Each of these is summarized below. In contrast to Thelma, Gloria did not always identify with science. In an assignment at the beginning of her teacher preparation program, Gloria reflected on her personal experiences 
with science. As a young person, she preferred other subject areas and did not see the relevance of science as it was taught in school to her own life.

When I was in school, I never expected to be a "science person." I liked reading and writing and assumed that I would eventually study something in the arts; even while I was applying for colleges, I marked "Literature" and "Anthropology" as potential majors. As such, she could understand how the youth she works with might not find science approachable, interesting or worthwhile, but also wanted to help change that. Just as particular educators opened her eyes to a different way of experiencing science, she wanted to do the same through her work with youth.

In my senior year of high school, however, I took an AP Environmental Science course that changed my understanding of what science was... while I had always thought of science as sterile and boring, this class demonstrated that all of the things I already loved—animals, plants, looking at things and taking notes, asking questions, asking more questions - were science, and that science is engaging and dynamic and relevant in all aspects of life. When science became simultaneously approachable and exciting, I was engaged in a level I had not thought possible, and even though the course was rigorous, I wanted to learn the material because I was interested in it.

Gloria's high school experiences shaped not only her understanding about science, but her beliefs about teaching and learning. In a course assignment describing her teaching philosophy, she personally felt connected to science when presented as a subject that is engaging, dynamic, relevant, approachable and exciting. Gloria takes a "student-centered approach" and demonstrates an "interest in building students" confidence" by supporting them in rigorous 
science. She recognized how she herself was most successful as a student when science was presented this way and so these approaches resonated with her as an educator.

Before entering the secondary teacher preparation program, Gloria had been working in environmental and agricultural education in a variety of out-of-school settings. The I-position as an informal science educator defined to a great deal her transition to high school classroombased teaching.

I was thinking about possible changes and looking at similar work to mine and was struggling because my job is so rare. There are not many jobs for farm educators. There are not many full time jobs for farm educators. And also because I didn't want to move up in my position because once I moved up, I would either stop farming, which I loved, and I would stop working with young people, which I loved...They were really the highlight of my day, and because I only worked with them seven months out of the school year, I spent five months of the year in the winter kind of bummed out, and I missed working with young people. And so I figured that was probably a good sign that I should move towards a position and a career where I worked with young people for the majority of the time and that was the basis of my work.

As Gloria recalls in the interview excerpt above, she had extensive experience working with teenage youth and had been quite successful working with this age group in particular. She took pride in her ability to build positive relationships with the youth she worked with. In her interview, she said,

I enjoyed that I was good at it. I think I'm really good at relating to young people, and I can show them respect and love...they're always, I think, so humble and feisty and sweet 
DIALOGIC VIEW OF CAREER CHANGER SCIENCE TEACHER IDENTITY

and fascinating, and they are so, so opening and welcoming to people who give them respect and love.

Gloria's passion for working with youth and building relationships with and amongst them links to the formation of another I-position, that of a social justice proponent. Gloria was motivated to pursue a master's degree in secondary biology education because of the inequities that she found in the science education opportunities the youth she worked with had available to them in school, as evidenced in the following interview excerpt:

I saw my students, who were not getting super great educations, who couldn't go back to school for a week one year because the cafeteria caved in, versus right two miles down the road was a really prestigious school where the ACT scores were on average like 12 points higher. And so my students a lot of times spoke in a really frustrated way with public school, and at first it make me really frustrated with their schooling system, and then I kind of got motivated by it.

Here, we see how Gloria's experience as a student who at first felt excluded from science, her passion for working with young people in informal learning contexts where they felt energized to learn and participate in science, and a frustration with the inequities she saw within schools all come together within her desire to pursue a career change to high school science teaching.

\section{Disequilibrium and Restored Equilibrium}

In this section, we look at the intersection of participants' identity, beliefs, and practice to report on how Thelma and then Gloria each experienced I-position conflicts and, thus, disequilibrium. Specifically, despite being pleased with their new career overall, there were times in which both struggled to enact aspects of their new science teacher identity and questioned their decisions to enter high school teaching, leaving careers that they had felt 
DIALOGIC VIEW OF CAREER CHANGER SCIENCE TEACHER IDENTITY

comfortable in, if not completely satisfied by. We also outline the similarities in how each was able to overcome I-position conflicts and restore equilibrium by finding a way to integrate their competing I-positions.

\section{Thelma}

Disequilibrium: I-position conflicts. Overall, Thelma's career change has been positive. At the end of her first year, she shared in an interview,

I'm just so happy. What I was missing as a vet, where I'd be like, I didn't wake up looking forward to work. I would count down the hours till I got home from the clinic. And I was irritable. And that's not enjoying my life. And this past year it's been challenging. It definitely has...[I keep asking myself] am I differentiating enough? Am I engaging enough? All those challenges, even with them, [this year] I was happy to go to work. I was excited about being where I was.

Thelma is enjoying being immersed in the science content and the school environment that she enjoyed previously. The challenges feel worthwhile rather than draining and she is finding a degree of contentment that she was missing in her previous job.

Nonetheless, there have been moments of disequilibrium as she has had to balance competing I-positions of novice and expert, veterinary doctor and classroom teacher. This was especially true at the start of this past school year, having spent the summer back in her veterinary clinic to earn some extra money after paying for graduate school to earn her teaching degree and licensure. In an interview, she explains,

I struggled...I was a full-time doctor in the summer because the education program ended. I had my [teaching] job lined up but for the summer, I went back to being a [veterinary] clinician full time. And then, [the next Monday] literally stopped being a doctor. The next 
DIALOGIC VIEW OF CAREER CHANGER SCIENCE TEACHER IDENTITY

day was like, here's your classroom. And it was totally this identity crisis, for real.... I was always a student, or doctor. I didn't really know how to be a teacher really. I went through the [teacher education] program, I was a student teacher...[Nevertheless] that first day of being a full time teacher, it was like, 'I'm your teacher.' It was just hard. It was funny.

Here, Thelma realized that she was straddling two careers and the unique I-positions affiliated with them. She was largely unfulfilled in her career as a veterinary doctor, even though she was successful in that career and had already put in so much time, energy and resources to earn the degree it required. She also wasn't sure that she wanted to completely abandon that side of her. She questioned, if she was a teacher now, could she still identify as and work as a veterinary doctor? And, was there anything from her career in veterinary medicine that she might be able to bring to her classroom?

Restored equilibrium. While these moments of discontinuity were challenging initially, resolving these competing I-positions came from Thelma deciding to maintain her I-position as veterinary doctor in ongoing dialogic conversation with her I-position as educator, as shown in the interview excerpt below:

When I meet new people and like, 'Oh, what do you do?' And it's like, 'Mmm, I'm a teacher. And I'm a vet.' I haven't let that part of who I am go, and I don't plan to. I want to do both. I think I totally can have both of those parts of me.

This assertion of the two I-positions developed over time. During the teacher education program, Thelma rarely referred to her veterinary practice. Across her field work, students referred to her as Ms. rather than Dr. and she did not speak about her previous career much. Now that she is in her own classroom, her classroom door and her school email signature include DVM. Resolving 
DIALOGIC VIEW OF CAREER CHANGER SCIENCE TEACHER IDENTITY

I-position conflicts can take time. Data indicate that Thelma grew increasingly comfortable with embracing the two different I-positions, holding them separate in some situations and integrating them in others. In the end, she resisted feeling the need to choose one or the other indefinitely. Moreover, Thelma felt this integration of her identities and experiences would be beneficial for her students in the long term., saying in an interview,

I think that's the goal, to kind of bring in more of my medical stuff into my classroom...My goal was always trying to teach phenomenon-based, maybe bringing in some case studies from the clinic...It's something that I definitely want to do. Because that's a unique kind of aspect of being a teacher that not a lot of students have. So I do want to do that.

Thelma is especially looking forward to the start of a series of elective Project Lead the Way courses (Project Lead The Way, Inc., 2011) that are focused on biomedical interventions and innovations. A new course in this series will be offered for the first time at the school, with Thelma as the instructor. Thelma's embrace of being both a vet and a teacher further eased her career transition and demonstrates the both/and nature of dialogic relationships.

\section{Gloria}

Disequilibrium: I-position conflicts. There are examples of equilibrium, disequilibrium, and restored equilibrium as Gloria transitioned to her new career as a classroom teacher. As alluded to above, Gloria gravitated in her preparation program toward readings about culturally relevant pedagogy (Gay, 2000, Ladson-Billings, 1995), so much so that she selected the name Gloria for her pseudonym for this study. Gloria felt her personal ideals could be materialized and implemented via a classroom teaching profession. She had come to identify with science thanks to influential educators who made her feel like the content was relevant and she mattered as a 
student. However, at the start of student teaching she began questioning why she struggled, at first, to make the same happen for her high school Biology students. Just as she had herself shut down as a young student in a setting that felt impersonal and the learning irrelevant, she found her ninth grade students arriving to class unmotivated.

Despite prior success in developing positive working relationships with youth in her prior career and first half of her preparation program, during student teaching she found herself grappling with this aspect of the job that she had previously been "good at" and most enjoyed. This struggle resulted in feelings of frustration and dissatisfaction. While teacher preparation programs often spend significant time focused on pedagogy and content, these were not the areas she found most challenging. Instead, it was the relationship-building with students.

We see in Gloria's case the importance of an “individual teacher's agentic effort to strive toward continuity and individuality" (Hong, Greene, \& Lowery, 2017, p. 95). A critical moment for her was realizing firsthand some of the complications inherent in the formal education systems that she had previously critiqued, and even found herself to be part of the problem at one key moment. In an interview excerpt, Gloria reveals,

That's why my start of student teaching was so frustrating, because I knew how wonderful and meaningful those relationships could be in a smaller group...I knew [the trouble I was having] was because I wasn't establishing relationships. I didn't know about them. I didn't know about their lives. They didn't know about mine.

Here, Gloria realizes that she was not the sort of teacher she had wanted to become, and the teaching setting is not what she had imagined it would be. Implementing what she wanted for her teaching and her high school classroom was not as easy as it once seemed. 
Restored equilibrium. The conflict Gloria experienced was a critical step in her development as a classroom educator. In the following interview excerpt, she described how she found resolution for this conflict by seeking to regain continuity through a process of deep independent reflection followed by action.

I sat down with every single one of my students one on one and asked them, 'What motivates you? Why are you here?' But also, 'Who is a teacher that you think handles you really well?' Or 'What's a class that you really like and what do you do in that class that makes you excited and interested to learn?

Here, Gloria found a way to successfully integrate those aspects of her I-positions of informal educator, relationship-builder, and social justice proponent into her I-position of classroom teacher, thus regaining equilibrium: "And so being able to sort of bring that into, from my old context, into my new context was really helpful". Indeed, in the teaching philosophy statement written during the semester before student teaching, she had reflected: "Through working with high school students on a farm, I've seen how important it is to set a positive tone for each day with energy and by greeting each student”. Remembering this belief and approach that was effective in her previous career helped Gloria to overcome the challenge she was facing during student teaching.

\section{Discussion and Conclusion}

This study responds to the call for "a broader understanding of what constitutes teacher identity development, and how that understanding relates to current frameworks of science teacher identity development" (Avraamidou, 2014, p. 166). Our dialogic approach to conceptualizing teacher identity development over time combines post-modern views of identity most frequently seen within recent science education literature with complimentary modern 
views since we agree with Akkerman \& Meijer (2011) that “it is untenable to 'replace' these earlier characterizations with their postmodern opposites" (p. 309). Additional investigations into science teacher identity that embrace these complimentary perspectives are encouraged.

While findings from the two cases explored in this study are not necessarily generalizable, they offer insight about I-position conflicts and resolution for science teacher educators who have students like Thelma and Gloria in their teacher education programs and whose success they wish to promote. These two cases illustrate how career change teachers enter their teacher preparation programs with a backpack of I-positions and are exposed to new ones as they transition into their new career. From a dialogic perspective, the decision to change careers can be understood as part of the "continuous attempt to make the self a whole" (Hermans \& Kempen, 1993, p. 93) and synthesize various I-positions. Both Thelma and Gloria experienced a degree of dissatisfaction with their prior careers, despite being successful in them. There were specific I-positions that they were eager to more fully embrace by making a career change to pursue teaching.

This collection of varied I-positions offers positive and negative affordances. Positive affordances are a result of multiple I-positions speaking to each other. In this sense, I-positions can be additive, contributing to the expansion and reinforcement of one's sense of self. On the other hand, negative affordances can ensue if I-positions are subtractive; that is, they repel one another. In this study, there was a common theme of Thelma and Gloria experiencing disequilibrium as they transitioned into a new career due to I-position conflicts that arose as they each sought to balance competing I-positions that emerged. However, there was also a common theme of eventually integrating these competing I-positions in an effort to find unity and continuity. Analysis indicated that part of overcoming I-position conflicts was Thelma and 
Gloria realizing the value of embracing, rather than trying to suppress, their varied I-positions and experiences from previous careers. Yet, these realizations took place on their own, raising the question of whether our teacher preparation program could have done something more to support them in identifying and navigating their competing I-positions.

Whereas there is evidence in favor of tensions and conflicts as essential to the development of professional identity particularly for novice teachers (e.g., Danielowich, 2012; Varelas et al., 2005), there is counterargument (Saka et al., 2013) on how potentially counterproductive and debilitating these tensions can be. From a pedagogical perspective, then, it becomes critical for teacher education programs to acknowledge teachers as multi-positional carriers and identify educational experiences which can support teacher candidates' navigation of the complexity of their continually developing science teacher identities (Grier \& Johnston, 2012; Meijer, Oolbekkink, Pillen, \& Aardema, 2014; Rodgers \& Scott, 2008). We offer and then discuss recommendations for programs based on the extant literature and findings of this study.

Time, and space and structures can be made available for candidates to:

- explore and re-explore their evolving professional beliefs

- uncover and investigate their backpack of varied I-positions

- examine their learning processes and development

- identify professional tensions and consider possible resolutions

- encounter and discuss vignettes from other career-changers

A typical assignment in methods courses asks candidates to write an autobiography statement in relation to their life experiences with science, teaching and learning, students, schools, communities, etc. (Knowles \& Holt-Reynolds, 1991). This assignment can be 
augmented by asking candidates to also consider what implications they feel their life experiences will have for their own teaching and future classroom.

Building off of an approach described by the International Institute for the Dialogic Self (see www.dialogicalinstitute.com), candidates can be introduced to the notion of I-positions and then prompted to create an artistic composition that represents the variety of I-positions and emotions that they feel fits their experience. Teacher educators and programs can support careerchange teachers in building upon their varied I-positions and negotiating I-position conflicts such that they do not become insurmountable. The next two recommendations are intended with this particular focus in mind.

While reflection on the successful implementation of particular lessons or instructional practices is commonplace, student teachers rarely examine their own learning processes (Mansvelder-Longayroux, Beijaard, \& Verloop, 2007). Storyline tools are a way to prompt this sort of reflection (see, for example, Meijer, de Graaf, \& Meirink, 2011). Candidates can draw and then discuss with their peers and instructors lines that they depict their view of their own development over the semester or year. On this line they also indicate key positive and negative incidents, or where something took place for the better and for the worse. Arguing in favor of this approach, Meijer and colleagues (2014) note that, "What is striking is that such conversations were not characterized by a focus on the development of knowledge and skills, but a focus on discussing together what it means to that particular student teacher to be or become a teacher" (p.299).

These key incidents can be explored further in relation to professional identity and professional identity tensions that research shows beginning teachers candidates commonly experience. Pillen, Beijaard, and den Brok (2013) developed a questionnaire designed to map 
DIALOGIC VIEW OF CAREER CHANGER SCIENCE TEACHER IDENTITY

beginning teachers' professional identity tensions, feelings, and coping strategies. Building on this work, Van Der Wal, Oolbekkink- Marchand, Schaap, and Meijer (2019) coupled this questionnaire with open-ended questions prompting reflection on the emotional impacts and ways of dealing with the tension, or what they refer to as affective impacts and behavioral responses. Time can be dedicated to considering tensions, along with their influences and manifestations, with a focus on using these as learning opportunities, particularly as candidates discuss with one another potential ways of coping with and addressing the tensions (Meijer et al, 2014).

The cases presented in this study and other literature can be collected and shared as vignettes to aid this sort of reflection on tensions and especially the transition to teaching from other careers. Teachers' stories and narratives are potentially powerful forms of professional development, providing a window into other's experiences (Jalongo, 1992; Jalongo \& Isenberg, 1995). Career-changers like Thelma who experience a lack confidence when shifting from one career to another may benefit to know that they are not alone in feeling frustrated, humbled and out of their comfort zone at first (see Grier \& Johnston, 2012; Kelly, Gningue, \& Qian, 2015 for other examples). Together, the stories of Thelma and Gloria captured in this study may help other career changers to embrace their prior and current professional identities rather than feel that one needs to be given up.

Findings of this study also suggest there may be benefits to bringing a relationshipperspective (Spilt, Koomen, \& Thijs, 2011) to the exploration of teachers' professional tensions. How do career change teachers express and reflect upon their feelings about classroom relationships, and what influence do these relationships have on their professional and personal well-being? Gloria's case in particular illustrates how teacher-student relationships can be a 
DIALOGIC VIEW OF CAREER CHANGER SCIENCE TEACHER IDENTITY

source of motivation and joy as well as frustration and stress. Gloria's case also raises questions such as whether a certain level of transparency is required for effective relationship-building in the secondary science classroom. Coursework can introduce and make space for critical conversations about notions of authentic caring or cariño (Bartolomé, 2008; Valenzuela,1999) and Duncan-Andrade's (2009) critical hope. How might sharing these and other career changer teachers' stories expose ideological and political dimensions of teaching and of caring and loving (Bartolomé, 1994, 2008)? What do both of these cases suggest about the importance and impact of positive teacher-student relationships on adolescent students' academic and social outcomes (Fredricks, Blumenfeld \& Paris, 2004; National Research Council 2004; Suárez-Orozco, Pimentel \& Martin, 2009)?

The recommendations introduced above may have particular value for career changers. In one sense, any effort to facilitate the career transition is a function of how well teacher educators and other stakeholders are able to understand and support career changers in regard to the challenges they struggle with (Grier \& Johnston, 2012; Kelly, Gningue, \& Qian, 2015; MarcoBujosa et al., 2019; Saka et al., 2013; Youngs, Bieda \& Kim, 2019).

\section{Future Research}

Further research is needed to better understand the unique identity tensions that beginning science career change teachers face during their preparation and induction phase (Antink-Meyer \& Brown, 2017), how these change over time (Pillen et al., 2013), and what approaches to supporting beginning teachers spark positive and propelling growth (Youngs et al., 2019). The ways in which teacher educators make use of cases such as the ones presented in this and other literature, and the outcomes of such an approach, invite further investigation and reporting. 
Finally, exploring identity-related issues is intrinsically a longitudinal undertaking. Tracking change in I-positions and how potential conflicts emerge and are addressed over teachers' careers would further allow for depicting identity from a developmental perspective. For instance, what is the impact of alignment/misalignment between I-positions on teachers' pedagogical practices over time and how they progress as teachers gain further experience? The way the resolution or persistence of I-position conflicts impacts instructional practices and student outcomes is a question that invites further research using the dialogic framework employed in this study. 


\section{References}

Akkerman, S. F., \& Meijer, P. C. (2011). A dialogical approach to conceptualizing teacher identity. Teaching and Teacher Education, 27, 308--319.

Anthony, G., \& Ord, K. (2008). Change-of-career secondary teachers: Motivations, expectations and intentions. Asia-Pacific Journal of Teacher Education, 36, 359-376.

Antink-Meyer, A., \& Brown, R. A. (2017). Second-career science teachers' classroom conceptions of science and engineering practices examined through the lens of their professional histories. International Journal of Science Education, 39(11), 1511-1528.

Avraamidou, L. (2014). Studying science teacher identity: Current insights and future research directions. Studies in Science Education, 50(2), 145-179.

Avraamidou, L. (2019). Stories we live, identities we build: How are elementary teachers' science identities shaped by their lived experiences? Cultural Studies of Science Education, 14(1), 33-59.

Bartolomé, L. I. (1994). Beyond the methods fetish: Toward a humanizing pedagogy. Harvard Educational Review, 64(2), 173-194.

Bartolomé, L. I. (2008). Authentic cariño and respect in minority education: The political and ideological dimensions of love. International Journal of Critical Pedagogy 1(1):1-17.

Beijaard, D., Meijer, P. C., \& Verloop, N. (2004). Reconsidering research on teachers' professional identity. Teacher and Teacher Education, 20, 107-128.

Bukor, E. (2015). Exploring teacher identity from a holistic perspective: Reconstructing and reconnecting personal and professional selves. Teachers and Teaching, 21(3), 305-327.

Calabrese-Barton, A., Kang, H., Tan, E., O’Neill, T. B., Bautista-Guerra, J., \& Brecklin, C. (2013). Crafting a future in science: Tracing middle school girls' identity work over time and space. American Educational Research Journal, 50, 37-75.

Creswell, J. W. (1994). Research design: Qualitative and quantitative approaches. SAGE Publications.

Creswell, J. W. (2013). Qualitative inquiry and research design: Choosing among five approaches. SAGE Publications. 
Creswell, J. W., \& Creswell, J. D. (2018). Research design: Qualitative, quantitative, and mixed methods approaches. SAGE Publications.

Danielowich, R. M. (2012). Looking through different lenses: How preservice science teachers use practice-oriented reflections to negotiate more reform-minded identities. Journal of Science Teacher Education, 23(4), 323-346.

Day, C. (2012). New lives of teachers. Teacher Education Quarterly, 39(1), 7-26.

Duncan-Andrade, J. M. (2009). Note to educators: Hope required when growing roses in concrete. Harvard Educational Review, 79, 181-194.

Eick, C. J., \& Reed, C. J. (2002). What makes an inquiry-oriented science teacher? The influence of learning histories on student teacher role identity and practice. Science Education, 86, 401-416.

Eifler, K., \& Potthoff, D. (1998). Nontraditional teacher education students: A synthesis of the literature. Journal of Teacher Education, 49(3), 187-195.

Fredricks, J. A., Blumenfeld, P. C., \& Paris, A. H. (2004). School engagement: Potential of the concept, state of the evidence. Review of Educational Research, 74, 54-109.

Gay, G. (2000). Culturally responsive teaching: Theory, research and practice. Teachers College Press.

Grier, J. M., \& Johnston, C. C. (2009). An inquiry into the development of teacher identities in STEM career changers. Journal of Science Teacher Education, 20(1), 57-75.

Grier, J. M, \& Johnston, C. C. (2012). STEM professionals entering teaching: Navigating multiple identities. Journal of Science Teacher Education, 23(1), 19-44.

Haggard, C., Slostad, F., \& Winterton, S. (2006). Transition to the school as workplace: Challenges of second career teachers. Teaching Education, 17(4), 317-327.

Helms, J. (1998). Science and me: Subject matter and identity in secondary school science teachers. Journal of Research in Science Teaching, 35(1), 811-834.

Hermans, H. J. M., \& Kempen, H. J. G. (1993). The dialogical self: Meaning as movement. Academic Press.

Hong, J., Greene, B., \& Lowery, J. (2017). Multiple dimensions of teacher identity development from pre-service to early years of teaching: A longitudinal study. Journal of Education for Teaching, 43(1), 84-98. 
Jalongo, M. R. (1992). Teachers' stories: Our ways of knowing. Educational Leadership, 49(7), $68-73$.

Jalongo, M. R., \& Isenberg, J. P. (1995). Teachers' stories: From personal narrative to professional insight. San Francisco: Jossey-Bass

Kelly, A., Gningue, S., \& Qian, G. (2015). First-Year Urban Mathematics and Science Middle School Teachers: Classroom Challenges and Reflective Solutions. Education and Urban Society, 47(2), 132-159.

Knowles, J.G. \& Holt-Reynolds, D. (1991) Shaping pedagogics through personal histories in preservice teacher education. Teachers College Record, 93, 87-113.

Ladson-Billings, G. (1995). Toward a theory of culturally relevant pedagogy. American Educational Research Journal, 32(3), 465-491.

Luehmann, A. L. (2007). Identity development as a lens to science teacher preparation. Science Education, 91(5), 822-839.

Marco-Bujosa, L. M., McNeill, K. L., \& Friedman, A. A. (2019). Becoming an urban science teacher: How beginning teachers negotiate contradictory school contexts. Journal of Research in Science Teaching, 57, 3-32.

Merriam, S. Sh., \& Tisdell, E. J. (2015). Qualitative research: A guide to design and implementation. San Francisco: Jossey-Bass.

Meijer, P. C., de Graaf, G., \& Meirink, J. A. (2011). Key experiences in student teachers' development. Teachers and Teaching: Theory and Practice, 17(1), 115_129.

Meijer, P.C., Oolbekkink, H.W., Pillen, M. \& Aardema, A. (2014). Pedagogies of Developing Teacher Identity. In Craig, C. \& Orland-Barak, L. (Eds.) International teacher education: Promising pedagogies Part A (pp. 293-310). Bingley: Emerald Group Publishing Limited.

Moore, F.M. (2012). Positional identity as a lens for connecting elementary preservice teachers to teaching in urban classrooms. In Varelas, M. (Ed.). Identity construction and science education research (pp. 105-121). Rotterdam: Sense Publishers.

National Research Council. (2004). Engaging schools: Fostering high school students' motivation to learn. Washington, DC: National Academies Press. 
Olsen, B. (2008). How reasons for entry into the profession illuminate teacher identity development. Teacher Education Quarterly, 35(3), 23-40.

Pillen, M., Beijaard, D., \& den Brok, P. (2013). Tensions in beginning teachers' professional identity development, accompanying feelings and coping strategies. European Journal of Teacher Education, 36(3), 240-260.

Rivera Maulucci, M. S. (2013). Emotions and positional identity in becoming a social justice science teacher: Nicole's story. Journal of Research in Science Teaching, 50, 453-478.

Rodgers, C. R., \& Scott, K. H. (2008). The development of the personal self and professional identity in learning to teach. In M. Cochran-Smith, S. Feiman-Nemser, D. J. McIntyre, \& K. E. Demers (Eds.), Handbook of research on teacher education (pp. 732_755). New York, NY: Routledge.

Saka, Y., Southerland, S., Kittleson, A., \& Hutner, J. (2013). Understanding the induction of a science teacher: The interaction of identity and context. Research in Science Education, 43(3), 1221-1244.

Suarez-Orozco, C., Pimentel, A., \& Martin, M. (2009). The significance of relationships: Academic engagement and achievement among newcomer immigrant youth. Teacher's College Record, 111(3), 712-749.

Smith, L. K. (2005). The impact of early life history on teachers' beliefs: in-school and out-ofschool experiences as learners and knowers of science. Teachers and Teaching: Theory and Practice, 11, 5-36.

Spilt, J. L., Koomen, H. M. Y., \& Thijs, J. T. (2011). Teacher well-being: The importance of teacher-student relationships. Educational Psychology Review, 23, 457-477.

Troesch, L.M. \& Bauer, C.E. (2017). Second career teachers: Job satisfaction, job stress, and the role of self-efficacy. Teaching and Teacher Education, 67,389-398.

Upadhyay, B. (2009). Negotiating identity and science teaching in a high-stakes testing environment: An elementary teacher's perceptions. Cultural Studies of Science Education, 4, 569-586.

Valenzuela, A. (1999). Subtractive schooling: U.S.-Mexican youth and the politics of caring. Albany: State University of New York Press.

van der Wal, M., Oolbekkink-Marchand, H. W., Schaap, H., \& Meijer, P. C. (2019). Impact of early career teachers' professional identity tensions. Teaching and Teacher Education, 80, 59-70. 
Varadharajan, M., \& Schuck, S. (2017). Can career changers be game changers? Policy, research and practice concerning career changers. In J. Nuttall, A. Kostogriz, M. Jones, \& J. Martin (Eds.), Teacher education policy and practice (pp. 83-95). Springer.

Varelas, M. (2012). Identity construction and science education research. Sense Publishers.

Varelas, M., House, R., \& Wenzel, S. (2005). Beginning teachers immersed into science: scientist and science teacher identities. Science Education, 89, 492-516.

Watters, J. J., \& Diezmann, C. M. (2015). Challenges confronting career-changing beginning teachers: A qualitative study of professional scientists becoming science teachers. Journal of Science Teacher Education, 26(2), 163-192.

Wilson, E., \& Deaney, R. (2010). Changing career and changing identity: How do teacher career changers exercise agency in identity construction? Social Psychology of Education, 13(2), 169-183.

Youngs, P., Bieda, K., \& Kim, J.(2019).Teacher Induction Programs Associated with Retention in the STEM Teaching Workforce. American Association for the Advancement of Science. 